\title{
Campydoroides manautei gen. et sp. nov. from New Caledonia and a reappraisal of the suborder Campydorina (Nematoda)
}

\author{
Oleksandr HOLOVACHOV \\ Department of Zoology, Swedish Museum of Natural History, \\ Box 50007, SE-104 05 Stockholm, Sweden. \\ Email: oleksandr.holovachov@nrm.se \\ urn:lsid:zoobank.org:author:89D30ED8-CFD2-42EF-B962-30A13F97D203
}

\begin{abstract}
The new genus and species Campydoroides manautei Holovachov gen. et sp. nov. is placed in the suborder Campydorina and is characterised by a transversely striated cuticle without lateral alae, body pores or epidermal glands; somatic sensilla only on pharyngeal region and on tail; a truncate labial region with papilliform inner labial, outer labial and cephalic sensilla; a stirrup-shaped amphid with transverse slit-like opening; a conoid stoma with strongly cuticularised walls and large protrusible dorsal tooth; a cylindrical pharynx with distinct basal bulb but without valves; a large ovoid cardia; didelphic, amphidelphic female gonads with antidromously reflexed ovaries and without spermatheca; a transverse vulva; a straight vagina without pars refringens vaginae or epiptygmata; an elongate tail with caudal glands and spinneret. The new genus is similar to the genera Campydora Cobb, 1920 and Udonchus Cobb, 1913 in having papilliform labial and cephalic sensilla, a stirrup-shaped amphid with a transverse slit-like opening, a stoma with a well-developed protrusible dorsal tooth, and a muscular pharynx with a strongly developed basal bulb, but can be easily separated from both in details of a stoma morphology. The systematics of the suborder Campydorina is revised. Halirhabdolaimus Siddiqi, 2012 is synonymised with Syringolaimus de Man, 1888.
\end{abstract}

Keywords. Classification, fauna, morphology, revision, taxonomy.

Holovachov O. 2019. Campydoroides manautei gen. et sp. nov. from New Caledonia and a reappraisal of the suborder Campydorina (Nematoda). European Journal of Taxonomy 518: 1-23. https://doi.org/10.5852/ejt.2019.518

\section{Introduction}

Due to the remarkable geological history of New Caledonia, the flora and fauna of the archipelago has a high proportion of endemism, which has attracted the attention of taxonomists and biogeographers (Grandcolas et al. 2008). As a result, many large groups of organisms are relatively well known, with current research focusing more on the speciation and microendemism and less on the general floristic and faunistic surveys. Nematodes, on the other hand, have been largely overlooked in the past. The few existing taxonomic and faunistic papers list only sixty-nine non-animal-parasitic nematode species known from New Caledonia (Table 1). Of them, thirty-five are marine (Inglis 1968; Gourbault \& Decraemer 1991, 1993, 1994a, 1994b; Guo et al. 2008), while 34 are found in freshwater and terrestrial habitats (Andrássy 1978; Germani 1990; Germani \& Anderson 1991; Yeates 1992; Holovachov 2001; 
Table 1. Free-living and plant-parasitic nematode fauna of New Caledonia (originally described from New Caledonia are marked with an asterisk).

\begin{tabular}{|c|c|c|c|c|}
\hline & $\begin{array}{l}\text { Marine or } \\
\text { terrestrial }\end{array}$ & $\begin{array}{l}\text { Distribution in New } \\
\text { Caledonia }\end{array}$ & Reference & $\begin{array}{l}\text { Distribution (in } \\
\text { addition to New } \\
\text { Caledonia) }\end{array}$ \\
\hline \multicolumn{5}{|l|}{ MONONCHIDA } \\
\hline Prionchulus punctatus & terrestrial & Mt. Dzumac & Yeates (1992) & cosmopolitan \\
\hline Clarkus dorsalis* & terrestrial & $\begin{array}{l}\text { Port Laguerre, Paita, } \\
\text { Mt. Dzumac, Chutes de la } \\
\text { Madeleine }\end{array}$ & Yeates (1992) & putative endemic \\
\hline Clarkus ouinnensis* & terrestrial & Ouinne Valley, Mt Dzumac & Yeates (1992) & putative endemic \\
\hline Actus neocaledonensis* & terrestrial & Port Laguerre, La Foa & Yeates (1992) & Vietnam \\
\hline Mylonchulus ciradi* & terrestrial & Port Laguerre & Yeates (1992) & putative endemic \\
\hline Mylonchulus vasis* & terrestrial & Port Laguerre & Yeates (1992) & India \\
\hline Mylonchulus paitensis* & terrestrial & Paita & Yeates (1992) & Pakistan, Iran \\
\hline Mylonchulus ananasi* & terrestrial & Port Laguerre & Yeates (1992) & putative endemic \\
\hline Cobbonchus couleensis* & terrestrial & La Coulee & Yeates (1992) & putative endemic \\
\hline Cobbonchus altitudinarum* & terrestrial & $\begin{array}{l}\text { Montagne des Sources, } \\
\text { Ouinne Valley, Mt Dzumac }\end{array}$ & Yeates (1992) & putative endemic \\
\hline $\begin{array}{l}\text { Cobbonchus dzumaci* } \\
\text { syn. C. mauritianus }\end{array}$ & terrestrial & Mt. Dzumac & Yeates (1992) & Mauritius \\
\hline Cobbonchus orstomi* & terrestrial & $\begin{array}{l}\text { Pic du Pin, Montagne des } \\
\text { Sources, Champ de Bataille }\end{array}$ & Yeates (1992) & putative endemic \\
\hline Iotonchus lacuplanarum* & terrestrial & $\begin{array}{l}\text { Pic du Pin, Chutes de la } \\
\text { Madeleine }\end{array}$ & Yeates (1992) & putative endemic \\
\hline Iotonchus montanum* & terrestrial & Montagne des Sources & Yeates (1992) & putative endemic \\
\hline Iotonchus candelabri* & terrestrial & Champ de Bataille & Yeates (1992) & Vietnam \\
\hline Iotonchus recessus* & terrestrial & Montagne des Sources & Yeates (1992) & putative endemic \\
\hline Iotonchus trichurus & terrestrial & Port Laguerre & Yeates (1992) & cosmopolitan \\
\hline Mulveyellus monhystera & terrestrial & La Coulee & Yeates (1992) & circumtropical \\
\hline \multicolumn{5}{|l|}{ DORYLAIMIDA } \\
\hline Xiphinema fagesi* & terrestrial & Mt. Tandji & Germani (1990) & putative endemic \\
\hline Xiphinema ensiculiferum & terrestrial & not provided & $\begin{array}{l}\text { Grandison et al. } \\
(2009)\end{array}$ & $\begin{array}{l}\text { Indo-Malay and } \\
\text { Australasian }\end{array}$ \\
\hline \multicolumn{5}{|l|}{$\begin{array}{l}\text { ENOPLIDA } \\
\end{array}$} \\
\hline Paranticoma caledoniensis ${ }^{*}$ & marine & Baie Saint Vincent & Inglis (1968) & putative endemic \\
\hline Paramesacanthion barbae* & marine & Baie Saint Vincent & Inglis (1968) & putative endemic \\
\hline \multicolumn{5}{|l|}{ DESMODORIDA } \\
\hline Nudora nuda* & marine & $\begin{array}{l}\text { Baie Saint Vincent, Uvea } \\
\text { Lagoon }\end{array}$ & $\begin{array}{l}\text { Inglis (1968); } \\
\text { Guo et al. (2008) }\end{array}$ & Malaysia \\
\hline Chromaspirina dubia* & marine & Baie Saint Vincent & Inglis (1968) & putative endemic \\
\hline Croconema mawsonae* & marine & Baie Saint Vincent & Inglis (1968) & putative endemic \\
\hline Desmodora deconincki* & marine & Baie Saint Vincent & Inglis (1968) & Adriatic Sea \\
\hline Paradesmodora supplementatis* & marine & Baie Saint Vincent & Inglis (1968) & Tunisia \\
\hline $\begin{array}{l}\text { Xenodesmodora wieseri* } \\
\text { syn. Desmodora wieseri }\end{array}$ & marine & Baie Saint Vincent & Inglis (1968) & putative endemic \\
\hline Spirinia laevioides & marine & Uvea Lagoon & Guo et al. (2008) & $\begin{array}{l}\text { Indo-Malay and } \\
\text { Australasian }\end{array}$ \\
\hline Eubostrichus parasitiferus & marine & Uvea Lagoon & Guo et al. (2008) & circumtropical \\
\hline $\begin{array}{l}\text { Catanema cobbi* } \\
\text { syn. Laxus cobbi }\end{array}$ & marine & Baie Saint Vincent & Inglis (1968) & putative endemic \\
\hline Akanthepsilonema helleouetae* & marine & Ilot Signal & $\begin{array}{l}\text { Gourbault \& } \\
\text { Decraemer (1991) }\end{array}$ & putative endemic \\
\hline Epsilonema exoticum & marine & Yaté & $\begin{array}{l}\text { Gourbault \& } \\
\text { Decraemer (1994b) }\end{array}$ & French Polynesia \\
\hline
\end{tabular}


Table 1 (page 2 of 3 ).

\begin{tabular}{|c|c|c|c|c|}
\hline & $\begin{array}{l}\text { Marine or } \\
\text { terrestrial }\end{array}$ & $\begin{array}{l}\text { Distribution in New } \\
\text { Caledonia }\end{array}$ & Reference & $\begin{array}{l}\text { Distribution (in } \\
\text { addition to New } \\
\text { Caledonia) }\end{array}$ \\
\hline \multicolumn{5}{|l|}{ DESMODORIDA (cont.) } \\
\hline Epsilonema enigmaticum* & marine & Ilot Kouaré & $\begin{array}{l}\text { Gourbault \& Decraemer } \\
\text { (1994b) }\end{array}$ & putative endemic \\
\hline Glochinema phaleratum* & marine & Yaté Plage & $\begin{array}{l}\text { Gourbault \& Decraemer } \\
\text { (1993) }\end{array}$ & putative endemic \\
\hline Metaglochinema strigosum* & marine & Yaté Plage & $\begin{array}{l}\text { Gourbault \& Decraemer } \\
\text { (1993) }\end{array}$ & putative endemic \\
\hline Polkepsilonema firmatum* & marine & $\begin{array}{l}\text { Phare Amédée, Ile des Pins, } \\
\text { Ilot Signal, Ilot Régnière }\end{array}$ & $\begin{array}{l}\text { Gourbault \& Decraemer } \\
\text { (1994a) }\end{array}$ & putative endemic \\
\hline $\begin{array}{l}\text { Draconema eira* } \\
\text { syn. Dracograllus eira }\end{array}$ & marine & Baie Saint Vincent & Inglis (1968) & $\begin{array}{l}\text { Papua New } \\
\text { Guinea }\end{array}$ \\
\hline \multicolumn{5}{|l|}{ CHROMADORIDA } \\
\hline Chromadora macrolaimoides & marine & Uvea Lagoon & Guo et al. (2008) & cosmopolitan \\
\hline Atrochromadora denticulata & marine & Uvea Lagoon & Guo et al. (2008) & North Atlantic \\
\hline Prochromadorella ditlevseni & marine & Uvea Lagoon & Guo et al. (2008) & cosmopolitan \\
\hline Prochromadorella septempapillata & marine & Uvea Lagoon & Guo et al. (2008) & $\begin{array}{l}\text { North Atlantic, } \\
\text { Mediterranean }\end{array}$ \\
\hline $\begin{array}{l}\text { Euchromadora colesi* } \\
\text { syn. Parapinnanema colesi }\end{array}$ & marine & $\begin{array}{l}\text { Baie Saint Vincent, Uvea } \\
\text { Lagoon }\end{array}$ & $\begin{array}{l}\text { Inglis (1968); } \\
\text { Guo et al. (2008) }\end{array}$ & putative endemic \\
\hline Halichoanolaimus unicus* & marine & Baie Saint Vincent & Inglis (1968) & putative endemic \\
\hline $\begin{array}{l}\text { Richtersiella discorda* } \\
\text { syn. } R \text {. discorda }\end{array}$ & marine & Baie Saint Vincent & Inglis (1968) & Bay of Bengal \\
\hline \multicolumn{5}{|l|}{ ARAEOLAIMIDA } \\
\hline Parodontophora xenotricha & marine & Uvea Lagoon & Guo et al. (2008) & Polynesia \\
\hline Mesonchium angelae* & marine & Baie Saint Vincent & Inglis (1968) & putative endemic \\
\hline \multicolumn{5}{|l|}{ DESMOSCOLECIDA } \\
\hline Desmoscolex grandiamphis* & marine & Baie Saint Vincent & Inglis (1968) & putative endemic \\
\hline Tricoma spuria* & marine & Baie Saint Vincent & Inglis (1968) & putative endemic \\
\hline \multicolumn{5}{|l|}{ MONHYSTERIDA } \\
\hline Elzalia poli & marine & Uvea lagoon & Guo et al. (2008) & Gulf of Mexico \\
\hline Metalinhomoeus timmi* & marine & Baie Saint Vincent & Inglis (1968) & putative endemic \\
\hline Theristus pertenuis & marine & Uvea Lagoon & Guo et al. (2008) & $\begin{array}{l}\text { Atlantic, Baltic, } \\
\text { Mediterranean }\end{array}$ \\
\hline Daptonema svalbardense & marine & Uvea Lagoon & Guo et al. (2008) & Svalbard \\
\hline Siphonolaimus dorylus* & marine & Baie Saint Vincent & Inglis (1968) & putative endemic \\
\hline $\begin{array}{l}\text { Terschellingia gerlachi* } \\
\text { syn. T. longicaudata }\end{array}$ & marine & Baie Saint Vincent & Inglis (1968) & cosmopolitan \\
\hline \multicolumn{5}{|l|}{ PLECTIDA } \\
\hline Plectus brzeskii* & terrestrial & Mt. Mou & Holovachov (2001) & putative endemic \\
\hline \multicolumn{5}{|l|}{ RHABDITIDA } \\
\hline Bicirronema caledoniense* & terrestrial & $\begin{array}{l}\text { Mt. Ounda, Mt. Mandjéla, } \\
\text { Mt. Koghi }\end{array}$ & Andrássy (1978) & putative endemic \\
\hline Amphidirhabditis longipapillata* & terrestrial & Mt. Ounda & Andrássy (1978) & putative endemic \\
\hline Dolichodorus pellegrini* & terrestrial & Mt. Panié & Germani (1990) & putative endemic \\
\hline $\begin{array}{l}\text { Hemicriconemoides } \\
\text { scottolamassese }{ }^{*}\end{array}$ & terrestrial & Montagne des Sources & $\begin{array}{l}\text { Germani \& Anderson } \\
\text { (1991) }\end{array}$ & putative endemic \\
\hline Hemicriconemoides mangiferae & terrestrial & $\begin{array}{l}\text { Koumac, Pindai, Col des } \\
\text { Roussettes, not provided }\end{array}$ & $\begin{array}{l}\text { Germani \& Anderson } \\
\text { (1991); } \\
\text { Grandison et al. (2009) }\end{array}$ & cosmopolitan \\
\hline Helicotylenchus dihystera & terrestrial & not provided & Grandison et al. (2009) & cosmopolitan \\
\hline Helicotylenchus multicinctus & terrestrial & not provided & Grandison et al. (2009) & cosmopolitan \\
\hline
\end{tabular}


Table 1 (page 3 of 3 ).

\begin{tabular}{lllll}
\hline & $\begin{array}{l}\text { Marine or } \\
\text { terrestrial }\end{array}$ & $\begin{array}{l}\text { Distribution in New } \\
\text { Caledonia }\end{array}$ & Reference & $\begin{array}{l}\text { Distribution (in } \\
\text { addition to New } \\
\text { Caledonia) }\end{array}$ \\
\hline $\begin{array}{l}\text { RHABDITIDA (cont.) } \\
\text { Helicotylenchus pseudorobustus }\end{array}$ & terrestrial & not provided & Grandison et al. (2009) cosmopolitan \\
Tylenchulus semipenetrans & terrestrial & not provided & Grandison et al. (2009) cosmopolitan \\
Meloidogyne incognita & terrestrial & not provided & Grandison et al. (2009) cosmopolitan \\
Pratylenchus coffeae & terrestrial & not provided & Grandison et al. (2009) cosmopolitan \\
Radopholus similis & terrestrial & not provided & Grandison et al. (2009) cosmopolitan \\
Rotylenchulus reniformis & terrestrial & not provided & Grandison et al. (2009) cosmopolitan \\
\hline
\end{tabular}

Grandison et al. 2009), and include plant-parasitic nematodes (Germani 1990; Germani \& Anderson 1991; Grandison et al. 2009).

Forty-five species of nematodes were originally described from New Caledonia as new to science (Inglis 1968; Andrássy 1978; Germani 1990; Germani \& Anderson 1991; Gourbault \& Decraemer 1991, 1993, 1994a, 1994b; Yeates 1992; Holovachov 2001). Of these, Actus neocaledoniensis Yeates, 1992 and Iotonchus candelabri Yeates, 1992 were subsequently recorded from Vietnam (Nguyễn Vũ Thanh 2007; Vu Thi Thanh Tam 2015), Mylonchulus vasis Yeates, 1992 was found in India (Tahseen et al. 2013), Mylonchulus paitensis Yeates, 1992 is known from Pakistan (Tabassum et al. 2001) and Iran (Farahmand et al. 2009; Mahdikhani-Moghadam et al. 2017), Nudora nuda Inglis, 1968 from Malaysia (Shabdin et al. 2013), Desmodora deconincki Inglis, 1968 from the Adriatic Sea (Travizi \& Vidaković 1997; Travizi 2010), Paradesmodora supplementatis Inglis, 1968 from Tunisia (Beyrem \& Aissa 2000; Boufahja et al. 2014; Jouili et al. 2018), Dracograllus eira (Inglis, 1968) from Papua New Guinea (Decraemer 1988), and Richtersiella discorda Inglis, 1968 (now in genus Richtersia Steiner, 1916) from the Bay of Bengal (Bhanu et al. 2017). Cobbonchus dzumaci Yeates, 1992 was synonymised with Cobbonchus mauritanus (Williams, 1958), a species known from Mauritius. Terschellingia gerlachi Inglis, 1968 was recorded from the Adriatic Sea (Travizi \& Vidaković 1997), but is now synonymised with Terschellingia longicaudata de Man, 1907, a cosmopolitan species. The species listed above are not endemic to New Caledonia, because they have been found in other places. The remaining species have not been found anywhere else in the world and can be preliminary listed as endemic to New Caledonia (Table 1).

The samples were collected during field trips in 2017 and 2018 as part of the Our Planet Reviewed/La Planète Revisitée programme - New Caledonia expeditions (2016-2018), which were organized by the Muséum national d'Histoire naturelle (Paris) and the Conservatoire d'Espaces Naturels de NouvelleCalédonie. This paper is the first in a series describing new nematode taxa found during these sampling trips.

\section{Material and methods}

A total of 230 samples was collected in New Caledonia during 2017 and 2018 (Fig. 1). The majority of the samples was collected in freshwater, limno-terrestrial and terrestrial habitats. Since the nematode fauna of several rivers and lakes included marine elements, additional samples were collected in saltwater habitats (brackish lagoons, mangroves and marine littoral) for comparative purposes. Nematodes from non-marine habitats were extracted from samples using a modification of Whitehead tray extraction technique (Whitehead \& Hemming 1965) and immediately fixed in a 4\% formaldehyde solution in freshwater or in $95 \%$ ethanol. In some cases, the entire sample of substrate was fixed in $4 \%$ formaldehyde; in such cases nematodes were extracted from the samples using a decanting and sieving 
method (smallest mesh sizes: $45 \mu \mathrm{m}$ or $70 \mu \mathrm{m}$ ), followed by a centrifugation in Ludox HS-40 (Burgess 2001). For light microscopy, formaldehyde-preserved specimens were transferred to pure glycerine using the rapid method of Seinhorst (1959) as modified by De Grisse (1969). Permanent nematode mounts on the glass slides were prepared using the paraffin wax ring method. All curved structures were measured along the curved median line. Measurements are presented in $\mu \mathrm{m}$ as mean and (range) where appropriate (Table 3). General terminology follows Maggenti (2005). Type specimens are deposited in the collections of the National Museum of Natural History in Paris, France (MNHN) and of the Swedish Museum of Natural History in Stockholm, Sweden (SMNH).

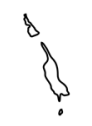

8

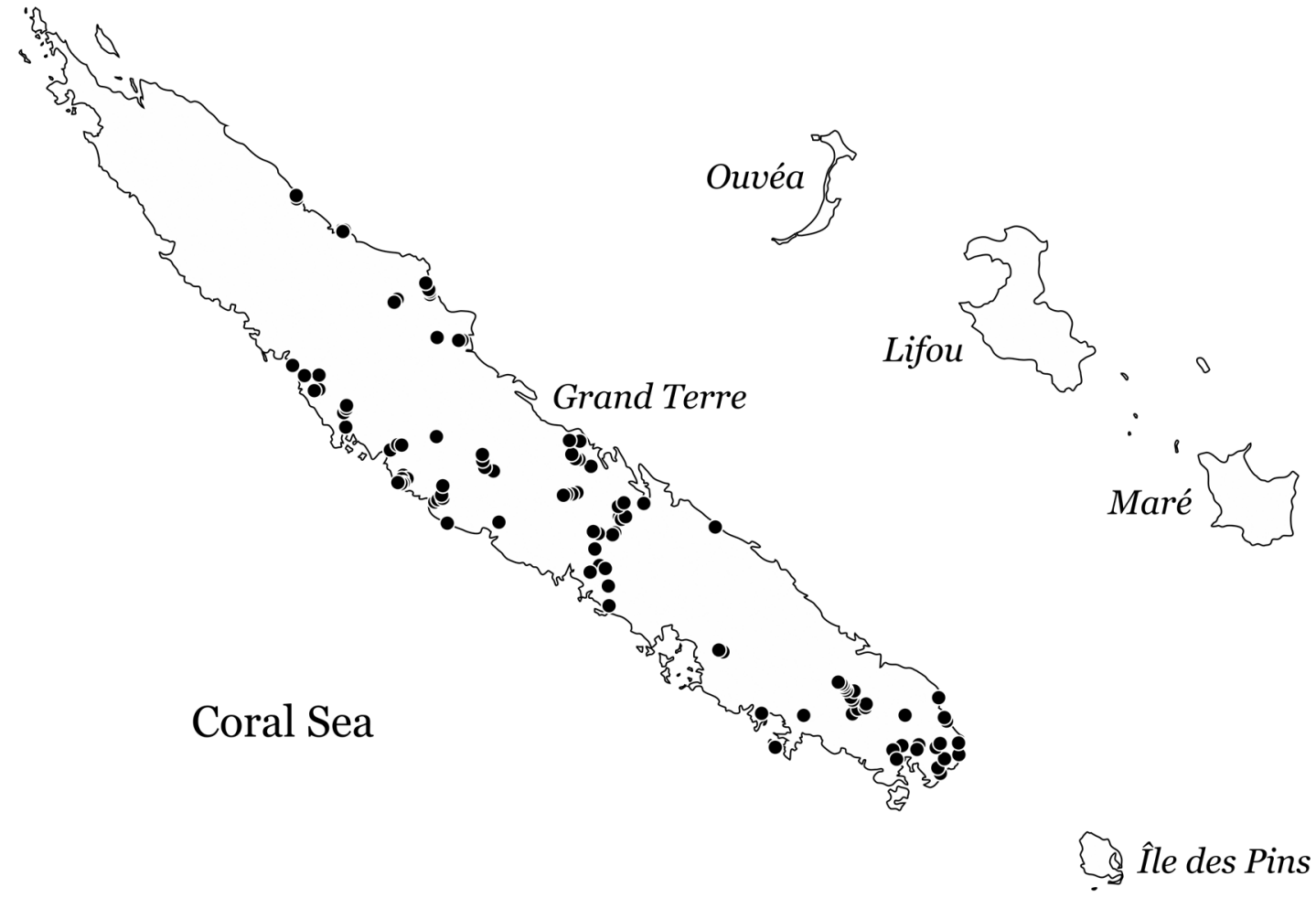

Fig. 1. Map of New Caledonia showing approximate position of sampled locations (modified from a map file available from https://d-maps.com/carte.php?num_car=15257). 


\title{
Results
}

\section{New genus and species}

\author{
Phylum Nematoda Potts, 1932 \\ Class Enoplea Inglis, 1983 \\ Order Enoplida Filipjev, 1929 \\ Suborder Campydorina Jairajpuri, 1983 \\ Superfamily Campydoroidea Thorne, 1935 \\ Family Campydoridae Thorne, 1935
}

\author{
Genus Campydoroides Holovachov gen. nov. \\ urn:1sid:zoobank.org:act:38D69C55-7ABA-4CBE-BF24-BDF8F136127E
}

\section{Diagnosis}

Cuticle transversely striated. Lateral alae, body pores and epidermal glands absent. Somatic sensilla distinct along anteriormost part of pharyngeal region and on tail. Labial region truncated. Six inner labial papilliform sensilla, located on anterior surface of lips. Six outer labial papilliform sensilla, located on periphery of labial region. Four cephalic papilliform sensilla, located a short distance behind labial region. Amphid stirrup-shaped with transverse slit-like opening. Stoma conoid, stegostom with strongly cuticularised walls and large protrusible dorsal tooth. Pharynx cylindrical anteriorly, with distinct basal bulb; valves absent. Cardia ovoid, partially embedded into intestinal tissue. Secretory-excretory system absent. Female reproductive system didelphic, amphidelphic, ovary branches reflexed antidromously. Vulva a transverse slit. Vagina straight, without pars refringens vaginae or epiptygmata. Spermatheca absent. Male reproductive system unknown. Tail elongate. Caudal glands and spinneret present.

\section{Type species}

Campydoroides manautei Holovachov gen. et sp. nov. (type by original designation).

\section{Relationships}

The new genus shows close affinities to the genera Campydora Cobb, 1920 and Udonchus Cobb, 1913 in having papilliform labial and cephalic sensilla, stirrup-shaped amphid with transverse slit-like opening, stoma with well-developed protrusible dorsal tooth, and muscular pharynx with stronglydeveloped basal bulb. The new genus differs from Campydora in detailed stoma morphology (conoid with strongly cuticularised walls and large dorsal tooth in Campydoroides gen. nov. vs cylindrical with weakly cuticularised walls and small dorsal tooth in Campydora), secretory-excretory system (absent in Campydoroides gen. nov. vs present in Campydora), cuticle (without longitudinal ridges in Campydoroides gen. nov. vs with ventral and dorsal ridges in Campydora) and tail (caudal glands and spinneret present in Campydoroides gen. nov. vs absent in Campydora). From Udonchus the new genus can also be easily separated by detailed stoma morphology (conoid with strongly cuticularised walls in Campydoroides gen. nov. vs cylindrical with weakly cuticularised walls in Udonchus) and number of teeth (single dorsal tooth in Campydoroides gen. nov. vs three small denticles in Udonchus). Further diagnostic characters separating the genus Campydoroides gen. nov. from all other genera considered in the suborder Campydorina are listed in the Table 2 and the identification key.

Overall morphology of the anterior end (papilliform labial and cephalic sensilla, stirrup-shaped amphid with transverse slit-like opening, stoma with well-developed dorsal tooth) is similar to that found in the members of the order Mononchida Jairajpuri, 1969 (Peña-Santiago 2014). However, the presence of a basal pharyngeal bulb in Campydoroides gen nov. is a feature never observed in any species of mononchid nematodes. In fact, the basal pharyngeal bulb is rarely present in non-chromadorean nematodes (those 


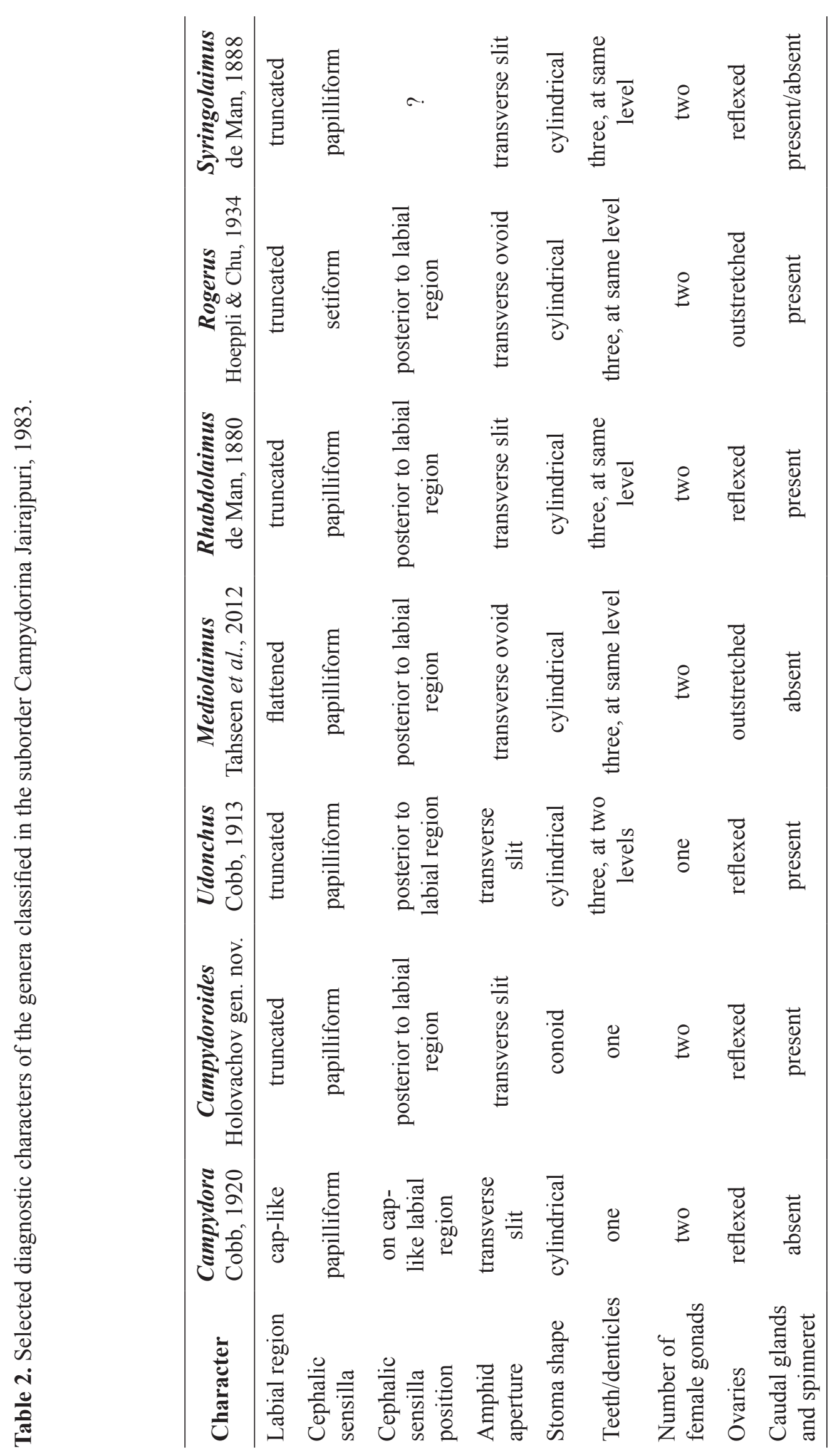


belonging to Enoplia Pearce, 1942 and Dorylaimia Inglis, 1983, see Schmidt-Rhaesa 2014), and is here considered one of the diagnostic features of the suborder Campydorina (see below).

Campydoroides manautei Holovachov gen. et sp. nov. urn:1sid:zoobank.org:act:CD624B5D-3F24-4D54-9C3C-C00615BB340E

Figs 2-4; Table 3

\section{Diagnosis}

Campydoroides manautei $\mathrm{sp}$. nov. is characterised by a $0.49-0.82 \mathrm{~mm}$ long body, papilliform inner labial, outer labial and cephalic sensilla, amphidial opening a transverse slit, strongly cuticularised stoma with single robust dorsal tooth, muscular pharynx with distinct basal bulb, large cardia, didelphic, amphidelphic female gonads, straight vagina, and elongate conoid tail equal to 6.0-9.6 anal body diameters in length.

\section{Etymology}

The new species is named in honour of Joseph Manauté, director of the Parc provincial de la Rivière bleue, for his indispensable support during the sampling in the Park.

\section{Type material}

\section{Holotype}

NEW CALEDONIA • 1 \&; Yate Province, Parc provincial de la Rivière bleue, station HYNC2372/4680; $22^{\circ} 04.401^{\prime} \mathrm{S}, 166^{\circ} 36.995^{\prime} \mathrm{E}$; 18 Jul. 2018; O. Holovachov leg.; virgin forest, soil; MNHN-BN511.

\section{Paratypes}

NEW CALEDONIA • 4 Q 9 ; Yate Province, Parc provincial de la Rivière bleue, station HYNC2372/4680; $22^{\circ} 04.401^{\prime} \mathrm{S}, 166^{\circ} 36.995^{\prime}$ E; 19 Nov. 2017 and 18 Jul. 2018; O. Holovachov leg.; virgin forest, soil; MNHN-BN511, SMNH Type-9167 • 2 우; Yate Province, Parc provincial de la Rivière bleue, station HYNC2378; 2205.374' S, $166^{\circ} 38.185^{\prime}$ E; 19 Nov. 2017; O. Holovachov leg.; virgin forest, wet soil at the bottom of a stream bed; SMNH Type-9168, SMNH Type-9169.

\section{Additional non-type material}

NEW ZEALAND • 2 우 ; Napier, Puketitiri, station Z236; 10 Nov. 1988; D. Sturhan leg.; SMNH175283.

\section{Description}

Female

Body cylindrical, tapering slightly along pharyngeal region towards truncated anterior end, tapering more rapidly along tail towards tail tip; straight or ventrally curved upon fixation. Cuticle finely transversely striated along entire body, starting from base of outer labial sensilla and ending near tail tip; striations less than $1 \mu \mathrm{m}$; lateral alae absent; any other types of cuticular ornamentation absent. Body pores and epidermal glands absent. Somatic sensilla distinct along anteriormost part of pharyngeal region (cervical setae, see below) and on tail, indistinct or absent along rest of body. Labial region truncated, lips indistinct (fused). Six inner labial sensilla small papilliform, located on anterior surface of lips. Six outer labial sensilla small papilliform, located on outer periphery of labial region, 1.5-5.0 $\mu \mathrm{m}$ from anterior end ( $5 \mu \mathrm{m}$ in specimen with everted stoma). Four cephalic sensilla small papilliform, located short distance behind lip region, 4-7 $\mu \mathrm{m}$ from anterior end, at level with dorsal tooth tip (in relaxed specimens, with inverted stoma, see below). Four pairs of cervical sensilla present, papilliform in shape, arranged in one dorsosublateral, one subdorsal and two subventral pairs at level of stoma base. Amphid stirrup-shaped with transverse slit-like opening 3-4 $\mu \mathrm{m}$ wide, located at level with middle of stoma. Oral opening 

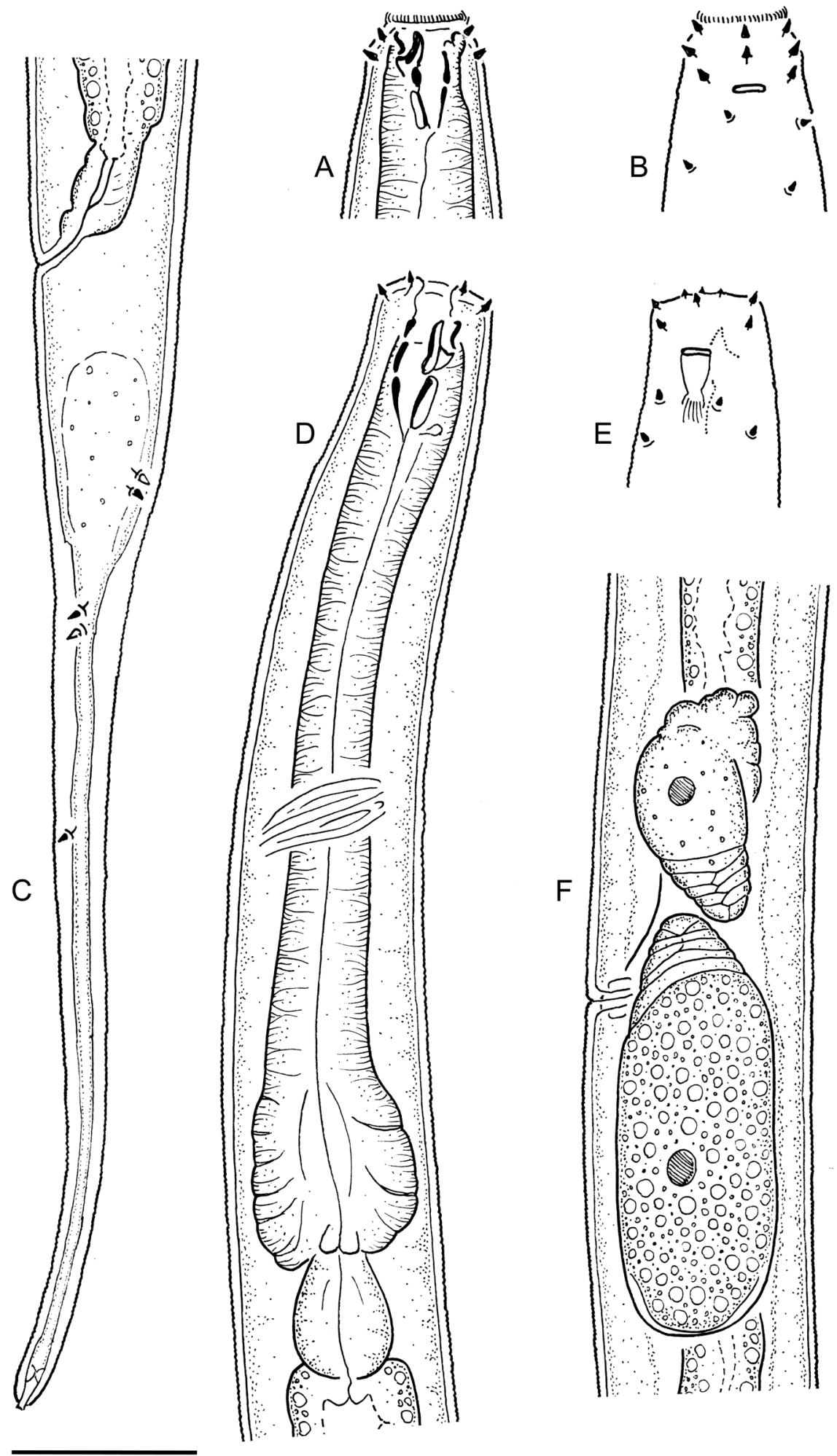

Fig. 2. Campydoroides manautei Holovachov gen. et sp. nov. A-B. Paratype female (SMNH Type9167). C-F. Holotype (MNHN-BN511). A. Female pharyngeal region, median section. B. Female anterior end, median section. C-D. Female anterior end, surface view. E. Female reproductive system. F. Female tail. Scale bar: $20 \mu \mathrm{m}$. 

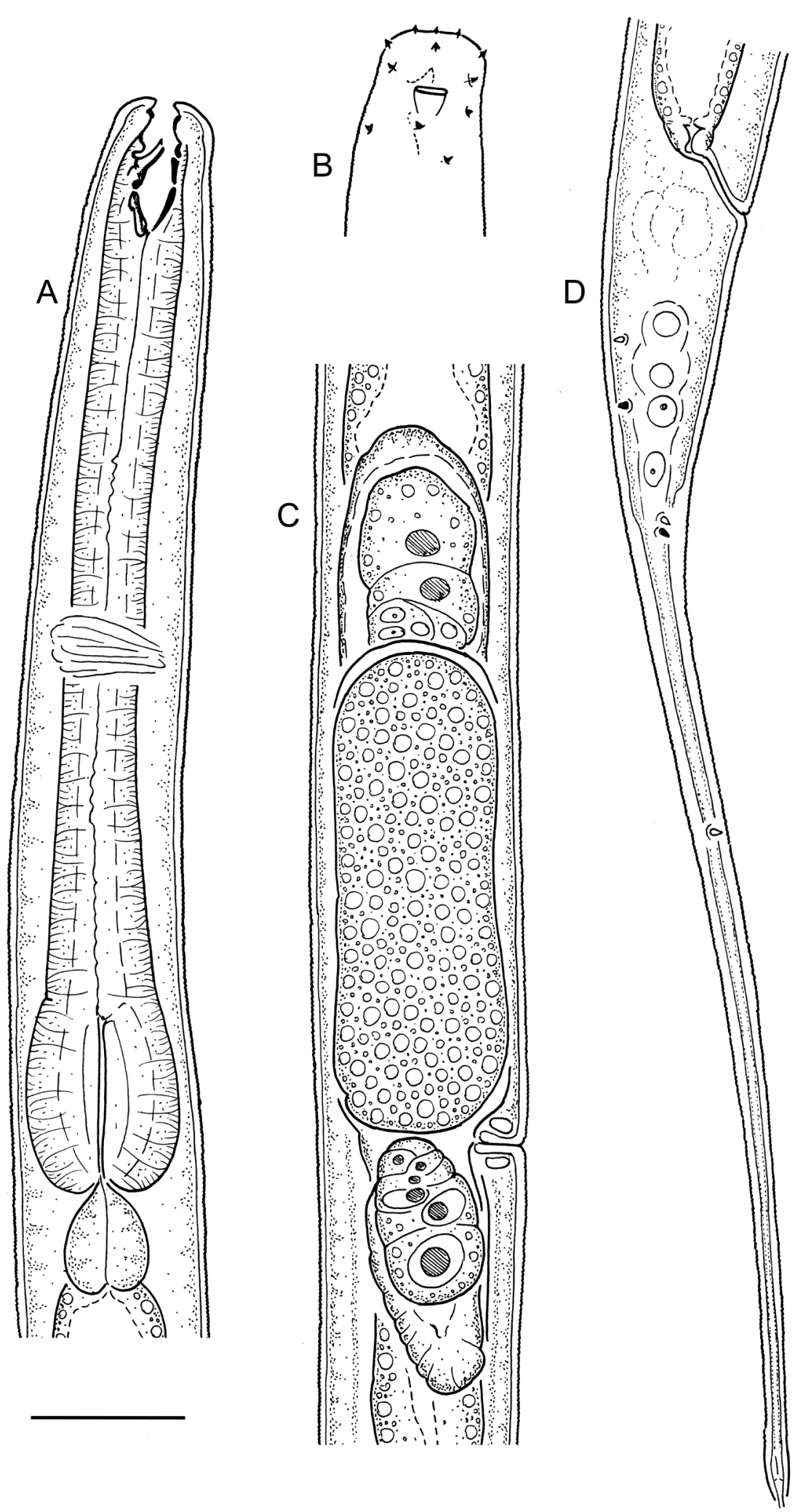

Fig. 3. Campydoroides manautei Holovachov gen. et sp. nov., non-type female from New Zealand (SMNH-175283). A. Female pharyngeal region, median section. B. Female anterior end, surface view. C. Female reproductive system. D. Female tail. Scale bar: $20 \mu \mathrm{m}$. 


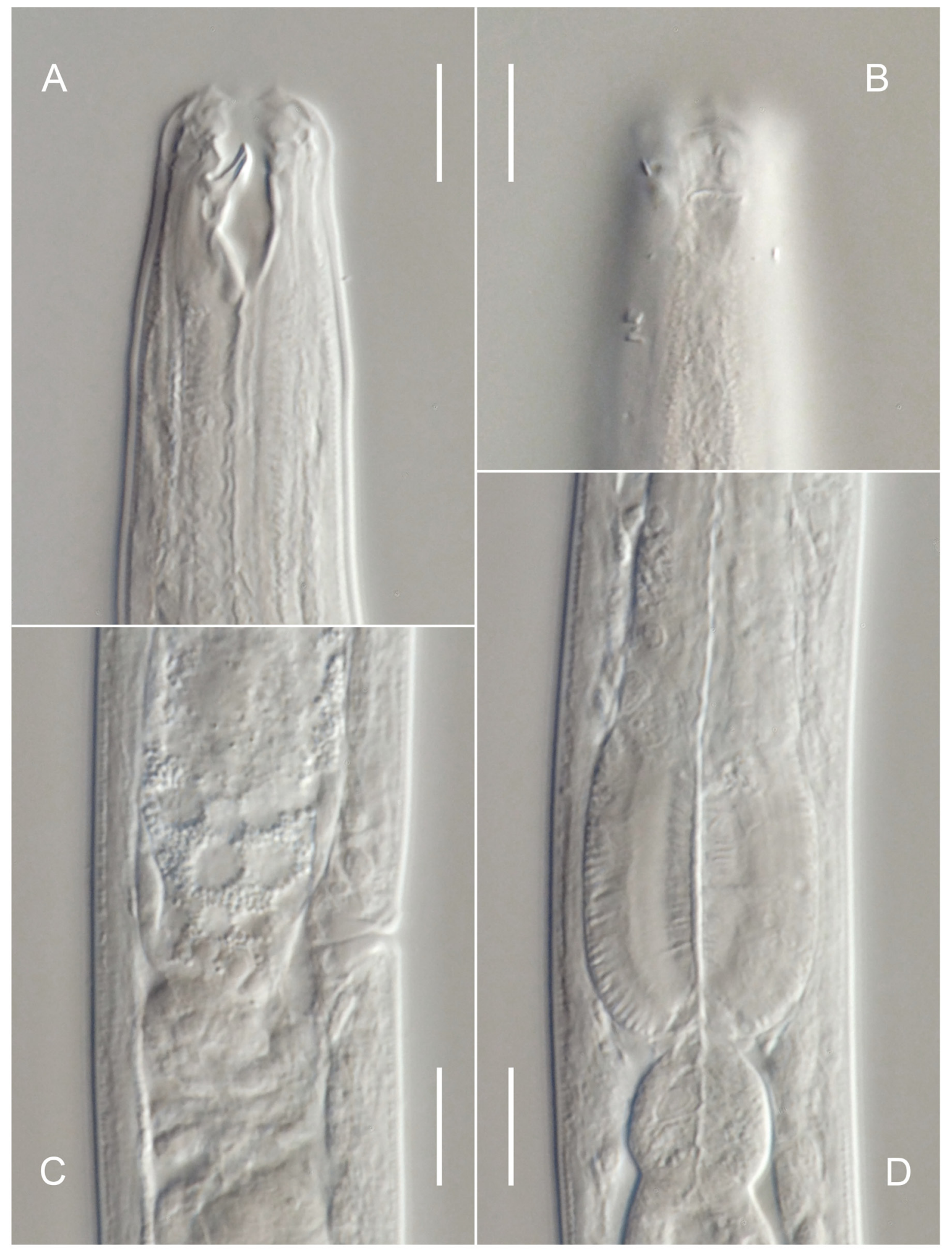

Fig. 4. Campydoroides manautei Holovachov gen. et sp. nov., non-type female from New Zealand (SMNH-175283). A. Anterior end, median section. B. Anterior end, surface view. C. Vulval region. D. Base of pharynx. Scale bar: $20 \mu \mathrm{m}$. 
Table 3. Morphometrics of Campydoroides manautei Holovachov gen. et sp. nov. (all measurements are in $\mu \mathrm{m}$, except for the ratios $a, b, c, c^{\prime}$ and $V$ ).

\begin{tabular}{lccc}
\hline Character & Holotype female & $\begin{array}{c}\text { New Caledonia }(\mathbf{n}=\mathbf{7}, \\
\text { incl. holotype) }\end{array}$ & New Zealand (n= 2) \\
\hline Body length & 609 & $537 \pm 45(492-609)$ & $786 ; 817$ \\
Body diameter & 26 & $24 \pm 3(19-28)$ & $25 ; 28$ \\
Pharynx length & 110 & $94 \pm 9(86-110)$ & $140 ; 146$ \\
Tail length & 128 & $115 \pm 9(104-128)$ & $173 ; 178$ \\
Anal body diameter & 16 & $16 \pm 1(15-17)$ & $18 ; 19$ \\
$a$ & 23.9 & $22.7 \pm 2(19.5-25.5)$ & $31.6 ; 29.6$ \\
$b$ & 5.6 & $5.7 \pm 0.4(4.9-6.1)$ & $5.6 ; 5.6$ \\
$c$ & 4.8 & $4.7 \pm 0.2(4.3-5.0)$ & $4.6 ; 4.6$ \\
$c$ & 8.0 & $7.1 \pm 0.8(6.0-8.0)$ & $9.6 ; 9.2$ \\
$V(\%)$ & 40.5 & $41.4 \pm 1.1(40.5-43.4)$ & $42.1 ; 42.6$ \\
Labial region diameter & 12 & $12(12-14)$ & $14 ; 14$ \\
Amphid from anterior end & 7 & $8(7-9)$ & $9 ; 8$ \\
Stoma length & 17 & $16(13-17)$ & $19 ; 17$ \\
Stoma width & 6 & $6(5-6)$ & $6 ; 6$ \\
Nerve ring from anterior end & 59 & $47 \pm 7(37-59)$ & $75 ; 76$ \\
Basal bulb length & 20 & $21 \pm 2(17-23)$ & $26 ; 23$ \\
Basal bulb width & 19 & $17 \pm 1(16-19)$ & $20 ; 21$ \\
Cardia length & 14 & $9 \pm 3(6-14)$ & $14 ; 15$ \\
Cardia width & 10 & $11 \pm 1(10-12)$ & $12 ; 12$ \\
Vagina length & 6 & $6(6-7)$ & $7 ; 7$ \\
Rectum length & 15 & $14 \pm 1(12-16)$ & $15 ; 15$ \\
Cardia width & 10 & $11 \pm 1(10-12)$ & $12 ; 12$ \\
Vagina length & 7 & $6(6-7)$ & $7 ; 7$ \\
Rectum length & 15 & $14 \pm 1(12-16)$ & $15 ; 15$ \\
\hline
\end{tabular}

apical, surrounded by a fringe of tiny projections, visible only when stoma is everted to the outside (Fig. 2A). Stoma conoid; cheilostom short and weakly cuticularised; gymnostom as long and broad as cheilostom, weakly cuticularised; stegostom with strongly cuticularised walls, distinctly subdivided into three sections by breaks in cuticularised walls, with large dorsal tooth projecting anteriad from its middle section. Tooth heavily cuticularised, $3-5 \mu \mathrm{m}$ long, hollow inside, protrusible, its tip is $10-13 \mu \mathrm{m}$ from stoma base. Pharyngeal tubes absent. Pharynx cylindrical anteriorly, with distinct basal bulb; anterior cylindrical part of pharynx with evenly distributed myofilaments, basal bulb strongly muscularised; pharyngeal lumen uniform in thickness along entire pharynx length; valves absent. Pharyngeal glands and their orifices indistinct. Cardia large, ovoid, partially embedded into intestinal tissue. Nerve ring encircling pharynx at $43-54 \%$ of its length. Secretory-excretory system indistinct/absent. Female reproductive system didelphic, amphidelphic, ovary branches reflexed antidromously, usually located on same side of intestine; symmetrical in younger females, asymmetrical in older females when large developing ovocyte or intrauterine egg is present in one of genital tubes. Anterior genital tube $21-91 \mu \mathrm{m}$ long, equal to $4-13 \%$ of total body length, situated to either right $(n=4)$ or left $(n=3)$ of intestine; posterior genital tube $23-55 \mu \mathrm{m}$ long, equal to $4-9 \%$ of total body length, situated to either right $(\mathrm{n}=3)$ or left $(n=4)$ of intestine. Vulva a transverse slit, located anterior to midbody. Vagina straight, equal to $0.2-0.3$ body diameters in length, with developed sphincter muscle surrounding its proximal part; pars refringens vaginae or epiptygmata absent. Spermatheca absent. Intrauterine egg measuring 64-77 × 17$21 \mu \mathrm{m}$. Rectum short, equal to $0.8-1.2$ anal body diameters in length. Tail elongate, distinctly subdivided 
into conoid proximal part 26-42 $\mu \mathrm{m}$ in length, and subcylindrical distal part 76-136 $\mu \mathrm{m}$ long. Caudal setae present, one subdorsal pair along proximal conoid part of tail, one subventral pair at level with junction between proximal and distal parts of tail, and single lateral setae on left side of distal cylindrical part of tail. Caudal glands present, opening via small terminal spinneret.

\section{Male}

Not found. The species is presumed to be thelytokous.

\section{Remarks}

The two female specimens collected in New Zealand match very well the morphology of the type specimens from New Caledonia, except for the larger body size, higher values for some body measurements and longer tail (including higher $c$ '-ratio). Since no qualitative morphological differences were found between the two populations, they both are here considered to belong to the same species.

\section{Notes on the systematics of Campydorina}

The unique and poorly understood morphology of the genus Campydora hindered understanding of its relationships with other nematodes and resulted in the taxonomic inflation from the genus to the suborder level (Jairajpuri 1983). This decision was followed in subsequent publications, although the suborder was transferred from the order Dorylaimida to the order Enoplida based on the morphological and molecular evidence, and its relationships within the order Enoplida remained unresolved (Siddiqi 1983; Winiszewska 2001; Mullin et al. 2003; Zhao et al. 2012; Smol etal. 2014). Subsequent phylogenetic studies using 18S rDNA sequence suggested close affinities between the genera Campydora, Rhabdolaimus de Man, 1880 and Syringolaimus de Man, 1888, placing these three genera as a monophyletic clade within the unresolved order Enoplida (Meldal et al. 2007; van Megen et al. 2009; Bik et al. 2010; Shokoohi et al. 2013; Smythe 2015; Leduc et al. 2018). This grouping can be further substantiated by at least one morphological character: the presence of a well-developed basal bulb, not found in any other Enoplida (the genera Polygastrophora de Man, 1922 and Belbolla Cobb, 1920 have the posterior part of the pharynx modified into a series of bulb-like swellings that are of independent origin). Placement of the genus Syringolaimus in the suborder Campydorina is further supported by the monorchic male reproductive system similar to the reproductive system found in the species from the genera Campydora and Rogerus (Hoeppli \& Chu 1932; Winiszewska 2001; Tchesunov 2017), while it is diorchic in other genera of Ironina Siddiqi, 1983 (Shokoohi et al. 2013; Chen \& Guo 2015). The revised classification of the suborder Campydorina is given below.

Superfamily Campydoroidea Thorne, 1935

\section{Diagnosis (modified from Smol et al. 2014)}

Cuticle finely striated. Lip region truncated or set off. Inner labial sensilla papilliform, outer labial sensilla and cephalic sensilla usually papilliform, sometimes setiform. Amphid with slit-like or transversely oval aperture and stirrup-shaped fovea. Stoma tubular or conoid, with one to three teeth. Pharynx cylindrical anteriorly, with distinct basal bulb; valves absent. Secretory-excretory pore present or absent. Female reproductive system didelphic, amphidelphic or monodelphic prodelphic. Ovary branches reflexed antidromously or outstretched. Males monorchic, testis outstretched, spicules paired and symmetrical. Caudal glands and spinneret present or absent.

\section{Included families}

Family Campydoridae Thorne, 1935.

Family Rhabdolaimidae Chitwood, 1951. 
Family Campydoridae Thorne, 1935

\section{Diagnosis}

As for the superfamily Campydoroidea, except that stoma with single dorsal tooth.

\section{Type genus}

Campydora Cobb, 1920.

\section{Included genera}

Campydora Cobb, 1920.

Campydoroides Holovachov gen. nov.

\section{Genus Campydora Cobb, 1920}

Diagnosis (based on Jairajpuri(1983) and Winiszewska (2001), supplemented with personal observations) Cuticle transversely striated, with dorsal and ventral longitudinal ridges. Lateral alae absent. Somatic sensilla not described. Labial region cap-like. Six inner labial papilliform sensilla, located on anterior surface of lips. Six outer labial papilliform sensilla, located on periphery of labial region. Four small papilliform cephalic sensilla, located just behind outer labial sensilla, on cap-like labial region. Amphid stirrup-shaped with transverse slit-like opening located on cap-like labial region. Stoma cylindrical, with weakly cuticularised walls and large protrusible dorsal tooth. Pharynx cylindrical anteriorly, with distinct basal bulb with strongly cuticularised lumen; valves absent. Cardia conoid, embedded into intestinal tissue. Secretory-excretory system present. Female reproductive system didelphic, amphidelphic, ovary branches reflexed antidromously. Vulva funnel-shaped, with transverse slit-like opening. Vagina straight, without pars refringens vaginae or epiptygmata. Spermatheca absent. Male reproductive system monorchic, testis outstretched. Spicules arcuate, symmetrical. Gubernaculum present. Precloacal supplements papilliform, in single midventral row. Caudal alae present. Tail conoid. Caudal glands and spinneret absent.

\section{Type and only species}

Campydora demonstrans Cobb, 1920.

Genus Campydoroides Holovachov gen. nov.

\section{Diagnosis}

See above.

\section{Type and only species}

Campydoroides manautei Holovachov gen. et sp. nov.

Family Rhabdolaimidae Chitwood, 1951

\section{Diagnosis}

As for the superfamily Campydoroidea, except stoma with three denticles.

\section{Included subfamilies}

Subfamily Monochromadorinae Andrássy, 1958.

Subfamily Rhabdolaiminae Chitwood, 1951. 
Subfamily Monochromadorinae Andrássy, 1958

Udonchinae Eyualem \& Coomans, 1996: 213.

\section{Diagnosis}

Cheilostom with twelve longitudinal rugae; stoma with three denticles, which are arranged in two separate groups at two levels; female reproductive system monodelphic.

\section{Type and only genus}

Udonchus Cobb, 1937.

\section{Genus Udonchus Cobb, 1913}

Monochromadora Schneider, 1937: 69.

Diagnosis (based on Eyualem \& Coomans (1996) and Tahseen et al. (2012))

Cuticle transversely striated. Lateral alae, body pores and epidermal glands absent. Somatic sensilla absent. Labial region truncated, lips fused. Six inner labial papilliform sensilla, located on anterior surface of lips. Six outer labial papilliform sensilla, located on periphery of labial region. Four cephalic papilliform sensilla, located short distance behind lip region. Amphid stirrup-shaped with transverse slit-like opening. Stoma tubular, cheilostom with 12 rugae, stegostom with cuticularised walls and three denticles (dorsal and ventral in anterior and left lateral in posterior parts of stoma). Pharynx cylindrical anteriorly, with distinct basal bulb; valves absent. Cardia conoid, not embedded into intestinal tissue. Secretory-excretory system absent. Female reproductive system monodelphic prodelphic, ovary branch reflexed antidromously. Vulva a transverse slit. Vagina oblique, without pars refringens vaginae or epiptygmata. Spermatheca absent. Male reproductive system unknown. Tail elongate. Caudal glands and spinneret present.

\section{Type species}

Udonchus tenuicaudatus Cobb, 1913.

syn. Chromadora monohystera Micoletzky, 1915.

syn. Udonchus monohystera (Micoletzky, 1915).

syn. Monochromadora monohystera tenuiformis Koniar, 1955.

syn. Udonchus monhystera tenuiformis (Koniar, 1955).

syn. Monochromadora monhysteroides Schneider, 1937.

syn. Monochromadora monhysteroides longicaudata Schneider, 1937.

\section{Included species}

Udonchus crassicauda (Schneider, 1937) Schiemer, 1978.

syn. Monochromadora crassicauda Schneider, 1937.

Udonchus merhatibebi Eyualem \& Coomans, 1996.

Subfamily Rhabdolaiminae Chitwood, 1951

Rogerinae Andrássy, 1976: 117.

\section{Diagnosis}

Cheilostom without rugae; stoma with three denticles arranged in one group, all at the same level; female reproductive system didelphic. 


\section{Type genus}

Rhabdolaimus de Man, 1880.

\section{Included genera}

Mediolaimus Tahseen, Sultana, Khan \& Hussain, 2012.

Rogerus Hoeppli \& Chu, 1934.

Syringolaimus de Man, 1888.

Genus Mediolaimus Tahseen, Sultana, Khan \& Hussain, 2012

Diagnosis (after Tahseen et al. 2012)

Cuticle transversely striated. Lateral alae absent. Somatic sensilla not described. Labial region flattened. Inner labial sensilla not described. Six outer labial pore-like sensilla. Four cephalic papilliform sensilla. Amphid with elliptical slit-like opening (transverse ovoid). Stoma tubular, cheilostom minute, stegostom with weakly cuticularised walls and three small denticles located at same level at its anterior edge. Pharynx cylindrical anteriorly, with distinct basal bulb; with thickened valve plates. Cardia small. Secretory-excretory system present. Female reproductive system didelphic, amphidelphic, ovary branches outstretched. Vulva a transverse slit. Vagina straight, with weak pars refringens vaginae, without epiptygmata. Spermatheca undescribed. Male reproductive system unknown. Tail elongate. Caudal glands and spinneret absent.

\section{Type and only species}

Mediolaimus obtusicaudatus Tahseen, Sultana, Khan \& Hussain, 2012.

Genus Rhabdolaimus de Man, 1880

Pseudorhabdolaimus Soós, 1937: 323.

Diagnosis (modified from Siddiqi 2012)

Cuticle transversely striated. Lateral alae, body pores and epidermal glands absent. Somatic sensilla absent. Labial region truncated, lips indistinct. Inner labial sensilla indistinct. Six outer labial pore-like sensilla, located on periphery of labial region. Four cephalic papilliform sensilla, located just behind labial region. Amphid stirrup-shaped with transverse slit-like opening. Stoma tubular, cheilostom minute, stegostom with weakly cuticularised walls and three small denticles located at same level at its anterior edge. Pharynx cylindrical anteriorly, with distinct basal bulb; valves absent. Cardia small, partially embedded into intestinal tissue. Secretory-excretory system absent. Female reproductive system didelphic, amphidelphic, ovary branches reflexed antidromously. Vulva a transverse slit. Vagina straight, without pars refringens vaginae or epiptygmata. Spermatheca absent. Male reproductive system unknown. Spicules arcuate, symmetrical. Gubernaculum, supplements and caudal alae absent. Tail elongate. Caudal glands and spinneret present.

\section{Type species}

Rhabdolaimus terrestris de Man, 1880.

syn. Rogerus rosea Ali, Suryawanshi \& Chisty, 1971.

\section{Included species}

Rhabdolaimus alpestris Siddiqi, 2012.

Rhabdolaimus annulatus Siddiqi, 2012.

Rhabdolaimus antiquus Siddiqi, 2012. 
Rhabdolaimus aquaticus de Man, 1880.

syn. Rhabdolaimus terrestris aquaticus de Man, 1880.

Rhabdolaimus brachyuris Meyl, 1954.

Rhabdolaimus directistomus Gagarin, 2000.

Rhabdolaimus hasani Siddiqi, 2012.

Rhabdolaimus limnophilus (Soós, 1937).

syn. Pseudorhabdolaimus limnophilus Soós, 1937.

Rhabdolaimus medius Siddiqi, 2012.

Rhabdolaimus minor Cobb, 1914.

Rhabdolaimus nannus (Hoeppli, 1926).

syn. Chromadora nanna Hoeppli, 1926.

Rhabdolaimus parvulus Siddiqi, 2012.

Rhabdolaimus porifer Siddiqi, 2012.

Rhabdolaimus porosus Siddiqi, 2012.

Rhabdolaimus sclerorectum Tahseen, Chowdhary, Kulsum, Ahmad \& Jairajpuri, 2005.

Rhabdolaimus strialaimus Siddiqi, 2012.

Rhabdolaimus thornei Siddiqi, 2012.

Genus Rogerus Hoeppli \& Chu, 1934

\section{Diagnosis}

Cuticle transversely striated. Lateral alae, body pores and epidermal glands absent. Somatic sensilla absent. Labial region truncated, lips indistinct. Inner labial sensilla papilliform. Six outer labial sensilla papilliform or setiform, located on periphery of labial region. Four cephalic setiform sensilla, at level with outer labial sensilla. Amphid oval (transverse ovoid). Stoma tubular, cheilostom minute, stegostom with weakly cuticularised walls and three small denticles located at same level at its anterior edge. Pharynx cylindrical anteriorly, with distinct basal bulb; valves absent. Cardia small, partially embedded into intestinal tissue. Secretory-excretory system absent. Female reproductive system didelphic, amphidelphic, ovary branches outstretched. Vulva circular. Vagina straight, without pars refringens vaginae or epiptygmata. Spermatheca absent. Male reproductive system monorchic. Spicules arcuate, symmetrical. Gubernaculum, supplements and caudal alae absent. Tail elongate. Caudal glands and spinneret present.

\section{Type and only species}

Rogerus orientalis (Hoeppli \& Chu, 1932).

syn. Greenia orientalis Hoeppli \& Chu, 1932; Greeninema orientalis (Hoeppli \& Chu, 1932).

\section{Included species}

Rogerus rajastanensis Khera, 1966.

syn. Rhabdolaimus rajastanensis (Khera, 1966).

Genus Syringolaimus de Man, 1888

Halirhabdolaimus Siddiqi, 2012: 65 syn. nov.

Diagnosis (after Tchesunov 2017)

Cuticle visually smooth or transversely striated. Lateral alae absent. Somatic sensilla undescribed. Labial region truncated. Inner labial sensilla indistinct. Morphology of inner and outer labial sensilla unclear. Four cephalic small papilliform sensilla. Amphid stirrup-shaped with transverse slit-like opening. Stoma 
cylindrical, with cuticularised walls and three protrusible bifid teeth located at same level at anterior edge of stegostom. Pharynx cylindrical anteriorly, with distinct basal bulb; valves absent. Cardia large, ovoid, partially embedded into intestinal tissue. Secretory-excretory system present. Female reproductive system didelphic, amphidelphic, ovary branches reflexed antidromously. Morphology of vulva and vagina unknown. Male reproductive system monorchic, testis outstretched. Spicules arcuate, symmetrical. Gubernaculum present. Precloacal supplements papilliform, in single midventral row. Caudal alae absent. Tail elongate. Caudal glands and spinneret present or absent.

\section{Type and only species}

Syringolaimus striatocaudatus de Man, 1888.

syn. Syringolaimus striatocaudatus aberrans Micoletzky, 1924.

syn. Syringolaimus striatocaudatus steineri Micoletzky, 1924.

syn. Dolicholaimus propinquus Allgén, 1933.

syn. Dolicholaimus tenuicaudatus Allgén, 1932.

\section{Included species}

Syringolaimus annae Lima, Lins, Da Silva \& Esteves, 2009.

Syringolaimus elegans Tchesunov, 2017.

Syringolaimus filicaudatus Vitiello, 1970.

Syringolaimus loofi Gourbault \& Vincx, 1985.

syn. Halirhabdolaimus loofi (Gourbault \& Vincx, 1985).

Syringolaimus renaudae Gourbault \& Vincx, 1985.

Syringolaimus smolae Lima, Lins, Da Silva \& Esteves, 2009.

Syringolaimus striatocaudatus de Man, 1888.

Syringolaimus taniae Lima, Lins, Da Silva \& Esteves, 2009.

\section{Species inquirenda}

Syringolaimus brevicaudatus Micoletzky, 1922.

Syringolaimus caspersi Gerlach, 1951.

Syringolaimus lichenii (Nasira \& Turpeenniemi, 2002).

syn. Trissonchulus lichenii Nasira \& Turpeenniemi, 2002.

Syringolaimus marisalbi Platonova \& Mokievsky, 1994.

Syringolaimus smarigdus Cobb, 1928.

\section{Nomina nuda}

Syringolaimus gladiatus Bussau, 1993.

Syringolaimus ingens Bussau, 1993.

Syringolaimus nitidus Bussau, 1993.

Syringolaimus venustus Bussau, 1993.

\section{Remarks}

See Tchesunov (2017) for the most recent and comprehensive revision of the genus. The genus Halirhabdolaimus was proposed by Siddiqi (2012) for a single species, Syringolaimus loofi, and was only compared with the genus Rhabdolaimus. However, the author did not compare Halirhabdolaimus with Syringolamus. The differential diagnoses of both genera match perfectly and thus the proposal of the new genus was entirely unjustified. 
Key to the genera of the suborder Campydorina (see Table 2 for additional diagnostic characters)

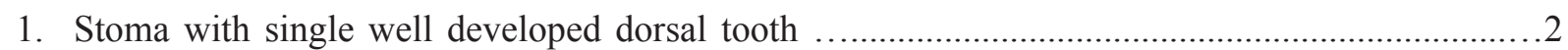

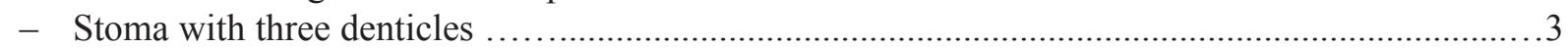

2. Stoma conoid with large tooth; cephalic sensilla and amphids posterior to labial region; caudal glands and spinneret present ...................................Campydoroides Holovachov gen. nov.

- Stoma cylindrical with small tooth; cephalic sensilla and amphids on cap-like labial region; caudal glands and spinneret absent

Campydora Cobb, 1920

3. Denticles located at different levels (dorsal and ventral in anterior and left lateral in posterior parts of stoma); female reproductive system monodelphic .....................Udonchus Cobb, 1913

- Denticles located at same level in anterior part of stoma; female reproductive system didelphic .....4

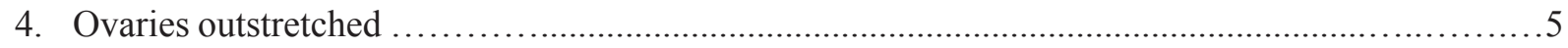

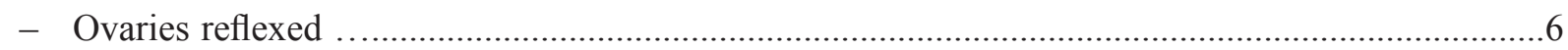

5. Cephalic sensilla setiform; caudal glands and spinneret present ...Rogerus Hoeppli \& Chu, 1934

- Cephalic sensilla papilliform; caudal glands and spinneret absent

Mediolaimus Tahseen, Sultana, Khan \& Hussain, 2012

6. Marine

Syringolaimus de Man, 1888

- Freshwater and terrestrial

Rhabdolaimus de Man, 1880

\section{Discussion}

The genera grouped in the suborder Campydorina differ from each other in the morphology of the stoma, which in the past was used as a reason to classify them in different orders of the phylum Nematoda. On the other hand, other systems of organs show similar morphology. These include the papilliform labial sensilla, the papilliform or short setiform cephalic sensilla, the stirrup-shaped amphid with transverse ovoid or slit-like aperture, the cylindrical and uniformly muscularised pharynx with a distinct basal bulb without valves or grinder, and the female reproductive system with simple vagina and short uteri. A similar pattern is observed in other groups of nematodes, such as in the families Chromadoridae Filipjev, 1917 and Diplogastridae Micoletzky, 1922, in which the general body plan is conserved, while the morphology of the stoma is extremely diverse (Sudhaus \& von Lieven 2003; Venekey et al., in press), reflecting various feeding strategies employed by different species of the same family.

\section{Acknowledgements}

The New Caledonia Hydrobiological expedition 2016-2018 (PI: Philippe Bouchet) is a part of a cluster of expeditions under the Our Planet Reviewed/La Planète revisité programme, implemented by the Muséum national d'Histoire naturelle; Pascale Joannot, Head of expeditions programme) in partnership with the Conservatoire d'Espaces naturels, with funding from the Gouvernement de la NouvelleCalédonie, Province Sud, Province Nord, Office des Postes et Télécommunications, Maison de la Nouvelle-Calédonie, and the French Ministry for the Overseas. The expedition operated under the permits issued by the Province Sud and the Province Nord, and the organisers thank, respectively, Emmanuel Coutures and Isabelle Jurquet (Province Sud) and Jean-Jérôme Cassan and Yannick Monlouis (Province Nord) for issuing of the permits. For logistics before, during, and after the field work, we thank Sébastien Faninoz and Alice Leblond. Our Planet Reviewed/La Planète revisitée is a global initiative founded in 2007 by the Muséum national d'Histoire naturelle and Pro-Natura International. The author is grateful to Nicolas Charpin, Kaj Hnauane and Christine Pöllabauer for their invaluable assistance during 2017 and 
2018 sampling trips, to Joseph Manauté, director of the Parc provincial de la Rivière bleue, for providing necessary facilities and permits, and to Grażyna Winiszewska, Museum and Institute of Zoology, Polish Academy of Sciences for providing specimens of Campydora demonstrans used in this study.

\section{References}

Andrássy I. 1978. Bicirronema caledoniense n. gen., n. sp. and Amphidirhabditis longipapillata n. gen., n. sp. (Secernentia: Rhabditida), two remarkable soil nematodes from New Caledonia. Revue de Nématologie 1: 257-263.

Beyrem H. \& Aissa P. 2000. Les nématodes libres, organismes-sentinelles de l'évolution des concentrations d'hydrocarbures dans la baie de Bizerte (Tunisie). Cahiers de Biologie marine 41: 329342. https://doi.org/10.21411/CBM.A.E84EC367

Bhanu C.V., Rao M.S., Annapurna C. \& Ambedkar A. 2017. Functional diversity of nematode communities in the Nizampatnam Bay, Bay of Bengal. Indian Journal of Geo Marine Sciences 46: $322-337$.

Bik H.M., Lambshead P.J.D., Thomas W.K. \& Lunt D.H. 2010. Moving towards a complete molecular framework of the Nematoda: a focus on the Enoplida and early-branching clades. BMC Evolutionary Biology 10: 353. https://doi.org/10.1186/1471-2148-10-353

Boufahja F., Vitiello P. \& Aissa P. 2014. More than 35 years of studies on marine nematodes from Tunisia: a checklist of species and their distribution. Zootaxa 3786: 269-300. https://doi.org/10.11646/zootaxa.3786.3.3

Burgess R. 2001. An improved protocol for separating meiofauna from sediments using colloidal silica sols. Marine Ecology Progress Series 214: 161-165. https://doi.org/10.3354/meps214161

Chen Y.Z. \& Guo Y.Q. 2015. Three new and two known free-living marine nematode species of the family Ironidae from the East China Sea. Zootaxa 4018: 151-175. https://doi.org/10.11646/zootaxa.4018.2.1

Decraemer W. 1988. Dracograllus (Nematoda: Draconematidae) from Papua New Guinea, with descriptions of new species. Leopold III Biological Station, Laing Island - Contribution no. 158. Bulletin de l'Institut royal des Sciences naturelles de Belgique, Biologie 58: 5-27.

De Grisse A.T. 1969 Redescription ou modifications de quelques techniques utilisées dans l'etude des nematodes phytoparasitaires. Mededelingen Rijksfakulteit Landbouwwetenschappen Gent 34: 351-369.

Eyualem A. \& Coomans A. 1996. Aquatic nematodes from Ethiopia VII. The family Rhabdolaimidae Chitwood, 1951 sensu Lorenzen, 1981 (Chromadorida: Nematoda) with the description of Udonchus merhatibebi n. sp. Hydrobiologia 341: 197-214. https://doi.org/10.1007/BF00014685

Farahmand S., Eskandari A., Orselli L. \& Karegar A. 2009. Some known species of the genera Mononchus Bastian, 1865 and Mylonchulus (Cobb, 1916) Altherr, 1953 (Nematoda: Mononchina) from Semnan province, Iran. Nematologia mediterranea 37: 145-154.

Germani G. 1990. Description of Dolichodorus pellegrini sp. n. (Nematoda: Dolichodoridae) and Xiphinema fagesi sp. n. (Nematoda: Dorylaimidae) from New Caledonia. Nematologica 36: 73-80. https://doi.org/10.1163/002925990X00040

Germani G. \& Anderson R.V. 1991. Taxonomic nots on some Hemicriconemoides specis and description of new species. Journal of Nematology 23: 502-510.

Gourbault N. \& Decraemer W. 1991. A new genus and species of Epsilonematidae (Nematoda) from New Caledonia. Zoologica Scripta 20: 315-319. https://doi.org/10.1111/j.1463-6409.1991.tb00296.x 
Gourbault N. \& Decraemer W. 1993. New species of Glochinema and Metaglochinema (Nematoda, Epsilonematidae) from New Caledonia. Zoologica Scripta 22: 223-227. https://doi.org/10.1111/j.1463-6409.1993.tb00353.x

Gourbault N. \& Decraemer W. 1994a. Polkepsilonema firmatum sp. n., a marine nematode (Nemata: Epsilonematidae) from New Caledonia. Nematologica 40: 485-493. https://doi.org/10.1163/003525994X00364

Gourbault N. \& Decraemer W. 1994b. Two new species of Epsilonema from South Indopacific (Nemata, Epsilonematidae). Journal of Nematology 26: 384-391.

Grandcolas F., Murienne J., Robillard T., Desutter-Grandcolas L., Jourdan H., Guilbert E. \& Deharveng L. 2008. New Caledonia: a very old Davinian island? Philosophical Transactions of the Royal Society $B$ 363: 3309-3317. https://doi.org/10.1098/rstb.2008.0122

Grandison G.S., Lebegin S. \& Lemerre Desprez Z. 2009. Plant-parasitic nematodes on economic crops of New Caledonia. Australasian Plant Pathology 38: 408-410. https://doi.org/10.1071/AP09016

Guo Y., Helléouet M.-N. \& Boucher G. 2008. Spatial patterns of meiofauna and diversity of nematode species assemblages in the Uvea lagoon (Loyalty Islands, South Pacific). Journal of the Marine Biological Association of the United Kingdom 88: 931-940. https://doi.org/10.1017/S002531540800146X

Hoeppli R. \& Chu H.J. 1932. Free-living nematodes from hot springs in China and Formosa. The Hong Kong Naturalist Supplement 1: 15-29.

Holovachov O. 2001. Description of Plectus (Ceratoplectus) brzeskii sp. nov. (Nematoda: Plectidae) from New Caledonia. Annales Zoologici 51: 1-4.

Inglis W.G. 1968. Interstitial nematodes from St. Vincent's Bay, New Caledonia. Expédition française sur les recifs coralliens de la Nouvelle Calédonie. Editions de la Fondation Singer-Polignac, Occasional Publications 2: 29-74.

Jairajpuri M.S. 1983. Observations on Campydora (Nematoda: Dorylaimida). Nematologia Mediterranea 11: $33-42$.

Jouili S., Semprucci F., Nasri A., Saidi I., Mahmoudi E. \& Essid N. 2018. Inventory of the free-living marine nematode species from el Bibane Lagoon (Tunisia). Arxius de Miscellània Zoològica 16: 1-19. https://doi.org/10.32800/amz.2018.16.0001

Leduc D., Zhao Z.Q., Verdon V. \& Xu Y. 2018. Phylogenetic position of the enigmatic deep-sea nematode order Rhaptothyreida: a molecular analysis. Molecular Phylogenetics and Evolution 122: 29-36. https://doi.org/10.1016/j.ympev.2018.01.018

Maggenti A.R. 2005. Online Dictionary of Zoology. Available from: http://digitalcommons.unl.edu/onlinedictinvertzoology/2 [accessed 11 Jan. 2019].

Mahdikhani-Moghadam E., Bub J.A.A., Chery S.B. \& Alvani S. 2017. Study of some mononchids (Nematoda: Mononchida) from Iran. Pakistan Journal of Nematology 35: 37-45.

van Megen H., van den Elsen S., Holterman M., Karssen G., Mooyman P., Bongers T., Holovachov O., Bakker J. \& Helder J. 2009. A phylogenetic tree of nematodes based on about 1,200 full length small subunit ribosomal DNA sequences. Nematology 11: 927-950. https://doi.org/10.1163/156854109X456862

Meldal B.H.M., Debenham N.J., De Ley P., De Ley I.T., Vanfleteren J.R., Vierstraete A.R., Bert W., Borgonie G., Moens T., Tyler P.A., Austen M.C., Blaxter M.L., Rogers A.D. \& Lambshead P.J.G. 2007. An improved molecular phylogeny of the Nematoda with special emphasis on marine taxa. Molecular Phylogenetics and Evolution 42: 622-636. https://doi.org/10.1016/j.ympev.2006.08.025 
Mullin P.G., Harris T.S \& Powers T.O. 2003. Systematic status of Campydora Cobb, 1920 (Nematoda, Campydorina). Nematology 5: 699-711. https://doi.org/10.1163/156854103322746878

Nguyễn Vũ Thanh. 2007. Fauna of Vietnam. 22. Monhysterida, Araeolaimida, Chromadorida, Rhabditida, Enoplida, Mononchida, Dorylaimida. Science and Technics Publishing House, Hà Noi.

Peña-Santiago R. 2014. Order Mononchida Jairajpuri, 1969. In: Schmidt-Rhaesa A. (ed.) Handbook of Zoology. Gastrotricha, Cycloneuralia and Gnathifera 2: 299-312. De Gryuter. https://doi.org/10.1515/9783110274257.299

Schmidt-Rhaesa A. (ed.) 2014. Handbook of Zoology. Gastrotricha, Cycloneuralia and Gnathifera. Vol. 2. De Gryuter. https://doi.org/10.1515/9783110274257

Seinhorst J.W. 1959. A rapid method for the transfer of nematodes from fixative to anhydrous glycerin. Nematologica 4: 67-69. https://doi.org/10.1163/187529259X00381

Shabdin M.L., Rosli N.M. \& Chen C.A. 2013. Free-living nematodes in Sarawak coastal waters. Penerbit UMT, Kuala Terengganu.

Shokoohi E., Mehrabi-Nasab A. \& Abolafia J. 2013. Studies on Ironus Bastian, 1865 (Enoplida: Ironidae) from Iran with a comment on its phylogenetic position. Nematology 15: 835-849. https://doi.org/10.1163/15685411-00002722

Siddiqi M.R. 1983. Phylogenetic relationships of the soil nematode orders Dorylaimida, Mononchida, Triplonchida and Alaimida, with a revised classification of the subclass Enoplia. Pakistan Journal of Nematology 1: 79-110.

Siddiqi M.R. 2012. Ten new species of Rhabdolaimus de Man, 1880, with the proposal for Halirhabdolaimus gen. n. (Nematoda: Haliplectidae). International Journal of Nematology 22: 47-66.

Smol N., Muthumbi A. \& Sharma J. 2014. Order Enoplida. In: Schmidt-Rhaesa A. (ed.) Handbook of Zoology. Gastrotricha, Cycloneuralia and Gnathifera 2: 193-250. De Gryuter. https://doi.org/10.1515/9783110274257.193

Smythe A.B. 2015. Evolution of feeding structures in the marine nematode order Enoplida. Integrative and Comparative Biology 55: 228-240. https://doi.org/10.1093/icb/icv043

Sudhaus W. \& von Lieven A. 2003. A phylogenetic classification and catalogue of the Diplogastridae (Secernentea, Nematoda). Journal of Nematode Morphology and Systematics 6: 43-90.

Tabassum K.A., Shahina F. \& Shaukat S.S. 2001. Three new records of the order Mononchida (Enoplida: Nematoda) from Pakistan. Pakistan Journal of Nematology 19: 41-47.

Tahseen Q., Sultana R., Khan R. \& Hussain A. 2012. A new genus and species of the family Rhabdolaimidae (Nematoda), with descriptions of two known species and taxonomic discussion. Journal of Nematology 44: 302-312.

Tahseen Q., Asil M., Mustaqim M., Ahlawat S. \& Bert W. 2013. Descriptions of ten known species of the superfamily Mononchoidea (Mononchida: Nematoda) from North India with a detailed account on their variations. Zootaxa 3646: 301-335. https://doi.org/10.11646/zootaxa.3646.4.1

Tchesunov A.V. 2017. Free-living nematodes of the genus Syringolaimus de Man, 1888 (Nematoda, Enoplida, Ironidae) from the Angola Basin, South-East Atlantic Abyss. Zootaxa 4306: 478-500. https://doi.org/10.11646/zootaxa.4306.4.2

Travizi A. 2010. The nematode fauna of the northern Adriatic offshore sediments: community structure and biodiversity. Acta Ardiatica 51: 169-180. 
Travizi A. \& Vidaković J. 1997. Nematofauna in the Adriatic Sea: review and check-list of free-living nematode species. Helgoländer Meeresuntersuchungen 51: 503-519. https://doi.org/10.1007/BF02908730

Venekey V., Gheller P.F., Kandratavicius N., Pereira Cunha B., Vilas-Boas A.C., Fonseca G. \& Maria T.F. 2019 [in press]. The state of the art of Chromadoridae (Nematoda, Chromadorida): a historical review, diagnoses and comments about valid and dubious genera and a list of valid species. Zootaxa.

Vu Thi Thanh Tam. 2015. New records of the genus Iotonchus (Mononchida, Iotonchidae) for Vietnam fauna and an updated key to species from Vietnam. Tap Chi Sinh Hoc 37: 272-281.

Whitehead A.G. \& Hemming J.R. 1965. A comparison of some quantitative methods of extracting small vermiform nematodes from soil. Annals of applied Biology 55: 25-38. https://doi.org/10.1111/j.1744-7348.1965.tb07864.x

Winiszewska G. 2001. Some observations on Campydora Cobb, 1920 (Nematoda), with descriptions of male Campydora demonstrans Cobb, 1920. Annales Zoologici 51: 391-394.

Yeates G. 1992. Nematodes from New Caledonia. 1. Introduction and Mononchoidea. Fundamental and applied Nematology 15: 101-126.

Zhao Z., Li D. \& Buckley T.R. 2012. Analysis of primary structure loops from Hairpins 35 and 48 of the Nematoda SSU rRNA gene provides further evidence that the genera Tripylina Brzeski, 1963, Trischistoma Cobb, 1913 and Rhabdolaimus de Man, 1880 are members of Enoplida. Zootaxa 3208: 41-57. https://doi.org/10.11646/zootaxa.3208.1.3

Manuscript received: 11 January 2019

Manuscript accepted: 21 March 2019

Published on: 23 April 2019

Topic editor: Rudy CAM Jocque

Desk editor: Alejandro Quintanar

Printed versions of all papers are also deposited in the libraries of the institutes that are members of the EJT consortium: Muséum national d'Histoire naturelle, Paris, France; Meise Botanic Garden, Belgium; Royal Museum for Central Africa, Tervuren, Belgium; Royal Belgian Institute of Natural Sciences, Brussels, Belgium; Natural History Museum of Denmark, Copenhagen, Denmark; Naturalis Biodiversity Center, Leiden, the Netherlands; Museo Nacional de Ciencias Naturales-CSIC, Madrid, Spain; Real Jardín Botánico de Madrid CSIC, Madrid, Spain; Zoological Research Museum Alexander Koenig, Bonn, Germany. 